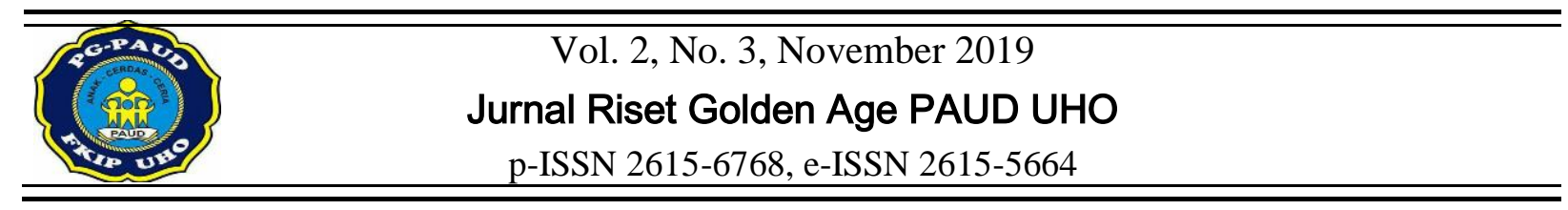

\title{
MENINGKATKAN KEMAMPUAN KOGNITIF ANAK MELALUI KEGIATAN KLASIFIKASI BENDA
}

\author{
Yuli Saputri ${ }^{1}$, Salwiah ${ }^{1)}$, Afifah Nur Hidayah ${ }^{1)}$ \\ ${ }^{1}$ Jurusan PG-PAUD, Universitas Halu Oleo. Jln. H.E.A Mokodompit, Kendari 93232, \\ Indonesia.
}

\begin{abstract}
Abstrak
Penelitian ini bertujuan untuk meningkatkan kemampuan kognitif anak melalui kegiatan klasifikasi benda di Kelompok B TK Tunas Mandiri Kabupaten Bombana. Subjek dalam penelitian ini adalah guru dan anak di kelompok B3 TK Tunas Mandiri Kabupaten Bombana yang berjumlah 16 orang anak didik yang terdiri atas 7 anak perempuan dan 9 anak laki-laki dengan rentang usia 5-6 tahun. Berdasarkan analisis data hasil observasi aktivitas mengajar guru pada siklus I diperoleh persentase ketercapaian sebesar 73,3\%, sedangkan aktivitas belajar anak didik diperoleh persentase ketercapaian sebesar $66,7 \%$. Pada siklus II, persentase ketercapaian aktivitas mengajar guru mengalami peningkatan menjadi $93,3 \%$, sedangkan persentase ketercapaian aktivitas belajar anak didik juga mengalami peningkatan menjadi $91,7 \%$ dan hasil belajar anak berupa peningkatan kemampuan kognitif anak melalui kegiatan klasifikasi benda meningkat sebesar 87,5\%.
\end{abstract}

Kata kunci: Kemampuan Kognitif, Anak, Kegiatan Klasifikasi Benda

\section{IMPROVING THE COGNITIVE ABILITY OF CHILDREN THROUGH CLASSIFICATION OBJECT ACTIVITIES}

\begin{abstract}
This study aims to improving the cognitive abilities of children through the classification objects in Group B TK Tunas Mandiri Bombana District. The subjects in this study were teachers and students in Group B TK Tunas Mandiri Bombana District, amounting to 16 students consisting of 7 girls students and 9 boys students with a range of age 5-6 years.. Based on data analysis result of observation teaching activities of teacher in first cycle obtained by percentage achievement of 73,3\% while the learning activities of the students obtained percentage achievement of 66,7\%.In the second cycle, the percentage achievement of teacher' teaching activities increased to 93,3\%, while the percentage of learning achievement of students also increased to $91,7 \%$ and the learning outcomesof students on improving the cognitive abilities of children through the classification obtained by the achievement of percentage to $87,5 \%$.
\end{abstract}

Keywords: Cognitive Ability, Children, Classification Object Activities

\section{PENDAHULUAN}

Undang-undang Nomor 20 Tahun 2003 tentang Sistem Pendidikan Nasional Pasal 1 ayat 14 menyatakan bahwa Pendidikan Anak Usia Dini (PAUD) adalah suatu upaya pembinaan yang ditujukan kepada anak sejak lahir sampai dengan usia enam tahun yang dilakukan melalui pemberian rangsangan pendidikan untuk membantu pertumbuhan dan perkembangan jasmani dan rohani agar anak memiliki kesiapan dalam memasuki pendidikan lebih lanjut.
Masa usia dini merupakan masa anak yang sering dipandang sebagai masa keemasan (golden age) bagi penyelanggara pendidikan dan hanya terjadi sekali dalam kehidupan manusia. Usia 4-6 tahun merupakan masa peka bagi anak. Masa peka adalah masa terjadinya pematangan fungsi-fungsi dan psikis yang siap merespon stimulasi yang diberikan oleh lingkungan. Masa ini merupakan masa untuk meletakan dasar pertama dalam mengembangkan potensi yang ada dalam diri anak, sehingga stimulasi atau rangsangan dari lingkungan sangat dibutuhkan 
untuk mengembangkan segala aspek perkembangan anak usia dini.

Pendidikan anak usia dini menitikberatkan pada aspek perkembangan fisik motorik, kognitif, bahasa, sosial emosional, serta nilai agama dan moral serta seni. Semua aspek tersebut harus distimulasi secara menyeluruh melalui proses pembelajaran. Salah satu kemampuan anak yang harus dikembangkan adalah kemampuan kognitif.

Pada aspek perkembangan kognitif, anak memiliki berbagai potensi yang harus dioptimalkan. Berdasarkan Peraturan Menteri Pendidikan Nasional No. 137 Tahun 2014 bahwa ada berbagai bagian yang termasuk dalam aspek perkembangan kognitif yang harus dikembangkan diantaranya belajar dan pemecahan masalah, berfikir logis, serta berfikir simbolik. Khusus pada sublingkup berfikir logis ada standar Tingkat Pencapaian Perkembangan (TPP) yang harus dapat dicapai oleh anak khususnya usia 5-6 tahun yaitu mampu mengklasifikasikan benda berdasarkan warna, bentuk, dan ukuran (3 variasi).

Kemampuan kognitif awal dari kemampuan anak untuk berpikir. Menurut Susanto (2011: 47) kognitif adalah suatu proses berpikir, yaitu kemampuan individu untuk menghubungkan, menilai, dan mempertimbangkan suatu kejadian atau peristiwa. Proses kognitif berhubungan dengan tingkat kecerdasan (inteligensi) yang menandai seseorang dengan berbagai minat terutama sekali ditujukan kepada ide-ide dan belajar.

Neiser yang dikutip oleh Khadijah (2016: 31) istilah Cognitive berasal dari kata Cognition yang padanannya Knowing yang berarti mengetahui. Dalam arti yang luas, Cognition ialah perolehan, penataan, dan penggunaan pengetahuan.

Susanto (2011:47) mengemukakan bahwa kognitif adalah suatu proses berpikir, yaitu kemampuan individu untuk menghubungkan, menilai, dan mempertimbangkan suatu kejadian atau peristiwa. Proses kognitif berhubungan dengan tingkat kecerdasan (inteligensi) yang menandai seseorang dengan berbagai minat terutama sekali ditujukan kepada ide-ide dan belajar.

Soemiarti Patmonodewo (2003:27) mengungkapkan bahwa kognitif adalah pengertian yang luas mengenai berpikir dan mengamati, jadi merupakan tingkah lakutingkah laku yang mengakibatkan orang memperoleh pengetahuan atau yang dibutuhkan untuk menggunakan pengetahuan.

Monks \& Knoers (2006: 208), kognisi adalah pengertian yang luas mengenai berpikir dan mengamati, jadi tingkah laku yang mengakibatkan orang memperoleh pengertian atau yang dibutuhkan untuk menggunakan pengertian.

Berk (Siti Partini Suardiman, 2003:1) menerangkan bahwa kemampuan kognitif menunjuk pada proses dan produk dari dalam akal pikiran manusia yang membawanya untuk tahu. Dalam hal ini termasuk semua kegiatan mental manusia yang meliputi: mengingat, menghubungkan, menggolonggolongkan, memberi simbol, mengkhayal, memecahkan masalah, mencipta dan membayangkan kejadian dan mimpi.

Witherington (2011: 53) mengemukakan bahwa kognitif adalah pikiran, melalui pikiran dapat digunakan bahwa dengan cepat dan tepat untuk mengatasi suatu situasi untuk memecahkan masalah. Adapun perkembangan kognitif adalah perkembangan pikiran. Pikiran adalah bagian dari proses dari otak, pikiran yang digunakan untuk mengenali, mengetahui, dan memahami.

Berdasarkan observasi awal yang dilakukan penulis dikelompok B TK Tunas Mandiri Kabupaten Bombana, pada saat pembelajaran menunjukan bahwa kemampuan kognitif anak terutama dalam kegiatan klasifikasi benda masih belum berkembang secara optimal dan masih tergolong rendah. Hal ini dapat terlihat ketika anak diminta untuk mengkasifikasikan benda berdasarkan warna, bentuk, ukuran serta pola dan ciri-ciri tertentu anak masih mengalami kebingungan, masih banyak ditemukan anak yang belum mampu mengklasifikasikan benda berdasarkan ciri tertentu. Hal ini disebabkan karena mereka jarang mengklasifikasikan benda secara langsung, sehingga menyebabkan sebagian besar anak masih mengalami kesulitan dalam kegiatan mengklasifikasi suatu benda berdasarkan ciri tertentu karena anak tidak terbiasa mengklasifikasikan benda secara langsung.

Mengelompokkan diartikan dengan mengklasifkasikan yaitu kemampuan untuk memilih benda berdasarkan kesamaan yang dimiliki ini merupakan suatu kegiatan yang popular untuk semua usia, kemampuan mengelompokkan sangat penting karena dapat mengasah kemampuan mengamati pada anak tentang persamaan dan perbedaan. 
Klasifikasi Menurut Kamus Besar Bahasa Indonesia (2005: 574) adalah penyusunan bersistem dalam kelompok atau golongan menurut standar atau standar yang ditetapkan, sedangkan mengklasifikasi menurut Kamus Besar Bahasa Indonesia (2005: 574) adalah menggolong-golongkan menurut jenis; menyusun ke dalam golongan.

Hildayani, dkk. (2005:9.30) klasifikasi adalah kemampuan untuk memilih dan mengelompokkan benda berdasarkan kesamaan yang dimiliki. Nugraha (2005: 129), mengklasifikasi merupakan suatu sistematika yang digunakan untuk mengatur obyek-obyek ke dalam sederetan kelompok tertentu. Kegiatannya antara lain: mencari persamaan obyek-obyek dalam suatu kelompok, menyusun obyek-obyek dalam suatu susunan berdasarkan pada sifat dan fungsinya yang dilakukan dengan membandingkan, mencari dasar pengklasifikasian obyek-obyek dengan mengkontraskan serta menggolongkan berdasarkan pada satu atau lebih ciri/sifat atau fungsinya.

Mengklasifikasi adalah bagaimana anak dapat menangani objek dalam jumlah yang banyak dengan mengelompokkannya sampai anak dapat melihat hubungan yang lebih sederhana dalam kumpulan yang kompleks. Secara umum materi klasifikasi di Taman Kanak-Kanak bertujuan unuk mengembangkan kemampuan untuk memilih dan mengelompokkan benda disekitanya berdasarkan kesamaan yang dimiliki menurut fungsi, bentuk, jenis, warna, pasangannya sesuai dengan yang dicontohkan dan tugas yang diberikan oleh guru. Suyanto (2005: 158) klasifikasi, yaitu mengelompokkan benda-benda ke dalam beberapa kelompok, untuk matematika bisa berdasarkan ukuran atau bentuknya.

Klasifikasi merupakan kegiatan mengelompokkan benda-benda yang serupa atau memiliki kesamaan (Seefeldt \& Barbara, 2008: 292). Sejalan dengan pengertian tersebut, Suyanto (2005: 162) mengemukakan bahwa klasifikasi adalah mengelompokan benda-benda ke dalam beberapa kelompok serta ciri tertentu.

Ginsburg dalam Seefeldt \& Barbara (2008: 292) agar anak usia dini mampu menggolongkan (mengklasifikasikan) atau menyortir benda-benda mereka harus memahami konsep "saling memiliki kesamaan atau keserupaan" dan "perbedaan". Ketika anak sudah mampu memahami konsep tersebut maka akan mudah dalam melakukan klasifikasi terhadap benda-benda. Klasifikasi juga tidak hanya didasarkan pada pengelompokan warna, bentuk, dan ukuran saja, akan tetapi juga dapat didasarkan pada ciri-ciri yang sama, jenis yang sama, ataupun kombinasi dari kategori-kategori tersebut

Kegiatan klasifikasi benda yang dilakukan dalam penelitian ini adalah kegiatan klasifikasi yang menggunakan benda kartu gambar buahbuahan. Dimana kegiatan yang dilakukan yaitu dengan menyuruh anak untuk mengklasifikasikan gambar buah berdasarkan warna merah tidak merah, berdasarkan bentuk lonjong tidak lonjong, berdasarkan ukuran besar tidak besar, dan berdasrakan ciri (kasar tidak kasar) yang ada pada gambar buah gambar tersebut.

\section{METODE}

Jenis penelitian yang digunakan pada penelitian ini oleh peneliti adalah Penelitian Tindakan Kelas (PTK). Igak Wardhani dan Kusmaya Wihardit (2010: 1.4) bahwa penelitian tindakan kelas merupakan suatu penelitian pula, yang dengan sendirinya mempunyai berbagai aturan dan langkah yang harus diikuti. Penelitian tindakan kelas merupakan terjemahan dari Classroom Action Research, yaitu Action Research yang dilakukan di kelas. Penelitian tindakan kelas adalah penelitian yang dilakukan oleh guru di dalam kelasnya sendiri melalui refleksi diri, dengan tujuan untuk memperbaiki kinerjanya sebagai guru, sehingga hasil belajar anak didik menjadi meningkat.

Penelitian ini dilaksanakan di kelompok B TK Tunas Mandiri Kecamatan Rumbia Tengah Kabupaten Bombana. Dan waktu penelitian dilaksanakan pada bulan April yaitu semester genap tahun akademik 2017/2018.

Subjek dalam penelitian tindakan kelas ini adalah guru dan anak didik di kelompok B TK Tunas Mandiri Kecamatan Rumbia Tengah Kabupaten Bombana. Dengan jumlah 16 orang anak didik yang terdiri atas 7 anak perempuan dan 9 anak laki-laki.

Adapun faktor-faktor yang diteliti dan diamati dalam penelitian ini yaitu: 1) Faktor anak, untuk mengamati aktivitas anak selama mengikuti proses pembelajaran di dalam kelas, untuk meningkatkan kemampuan kognitif anak melalui kegiatan klasifikasi benda. Kemampuan kognitif anak melalui kegiatan klasifikasi benda bertujuan agar anak mampu mengklasifikasikan benda berdasarkan warna, bentuk, ukuran, serta ciri tertentu; b) Faktor guru, untuk mengamati 
aktivitas mengajar guru dalam melaksanakan proses pembelajaran dalam meningkatkan kemampuan kognitif anak melalui kegiatan klasifikasi benda di kelompok B TK Tunas Mandiri Kecamatan Rumbia Tengah Kabupaten Bombana; c) Hasil belajar anak, untuk mengamati tentang peningkatan kemampuan kognitif anak melalui kegiatan klasifikasi benda.

Penelitian ini direncanakan dua siklus dan masing-masing siklus terdiri atas empat kali pertemuan. Secara umum, terdapat empat langkah dalam melakukan PTK, yaitu (1) perencanaan; (2) pelaksanaan; (3) pengamatan; (4) refleksi (Arikuntodalam Suyadi, 2010: 49).

Teknik pengumpulan data yang dilakukan pada penelitian ini dengan menggunakan cara pengamatan/observasi, wawancara, dan dokumentasi. 1) Pengamatan/observasi adalah suatu teknik yang dapat dilakukan guru untuk mendapatkan berbagai informasi atau data tentang perkembangan dan permasalahan anak. Melalui pengamatan, guru dapat mengetahui bagaimana perubahan yang terjadi pada anak dalam satu waktu tertentu, 2). Wawancara dilakukan dengan berkomunikasi kepada guru dan kepala sekolah. 3) Dokumentasi yang digunakan dalam penelitian ini adalah mengambil data anak berupa hasil karya anak pada saat melakukan proses pembelajaran di sekolah dan foto-foto dalam proses pembelajaran berlangsung sebagai data yang mendukung untuk dianalisis.

Teknik analisis data yang digunakan dalam penelitian ini disesuaikan dengan teknik penilaian di Taman Kanak-kanak yaitu dengan menggunakan tanda sebagai berikut: * = Belum Berkembang $(\mathrm{BB}), * *=$ Mulai Berkembang $(\mathrm{MB}), \quad * * *=$ Berkembang Sesuai Harapan $(\mathrm{BSH}), * * * *=$ Berkembang Sangat Baik (BSB) (Depdiknas, 2004: 26).

Indikator kinerja dalam penelitian ini ditetapkan oleh TK Tunas Mandiri Kabupaten Bombana, yang terdiri dari indikator proses pembelajaran dan indikator hasil (nilai) anak didik. Dari segi proses, tindakan dikatakan berhasil apabila hasil observasi terhadap guru dan anak telah mencapai persentase minimal $85 \%$ sesuai dengan skenario kegiatan pembelajaran dalam meningkatkan kemampuan kognitif anak melalui kegiatan klasifikasi benda. Dan dari segi hasil, apabila $85 \%$ anak memperoleh nilai $* * *$ maka kemampuan kognitif anak melalui kegiatan klasifikasi benda dapat dikatakan berhasil. Sebaliknya jika $85 \%$ anak yang memperoleh nilai ** berarti tindakan tersebut tidak berhasil dan perlu diadakan tindakan lanjutan.

\section{HASIL DAN PEMBAHASAN}

Sebelum kegiatan penelitian ini dilaksanakan, peneliti terlebih dahulu melakukan pertemuan awal dengan kepala TK Tunas Mandiri yaitu pada tanggal 29 Maret 2017, pertemuan ini bermaksud untuk menyampaikan tujuan dari peneliti yaitu mengadakan penelitian di TK Tunas Mandiri. Selanjutnya, kepala TK mengarahkan peneliti untuk berdiskusi dengan guru Kelompok B sekaligus sebagai observer/teman sejawat peneliti dalam pelaksanaan penelitian yang berkaitan dengan kegiatan yang akan dilakukan peneliti yaitu meneliti tentang meningkatkan kemampuan kognitif anak melalui kegiatan klasifikasi benda. Setelah itu, peneliti berbincang-bincang dengan guru kelompok B akhirnya mencapai kesepakatan untuk melakukan observasi awal pada tanggal 31 Maret 2017 sekaligus meminta kesediaan guru kelompok B sebagai observer peneliti dalam melaksanakan penelitian.

Berdasarkan hasil observasi dan dilanjutkan dengan wawancara singkat dengan guru kelompok B di taman kanak-kanak tersebut, menunjukan bahwa kemampuan Kognitif anak melalui kegiatan klasifikasi benda pada kelompok B Taman Kanak-kanak Tunas Mandiri masih terbilang rendah yaitu berada pada taraf MB (Mulai Berkembang) dan BB (Belum Berkembang) atau dengan simbol nilai bintang $(* *)$ dan $(*)$ sehingga perlu dikembangkan dan ditingkatkan lagi. Kurang meningkatnya kemampuan kognitif anak disebabkan oleh jarangnya pengklasifikasian benda secara langsung oleh anak dan kurangnya media yang digunakan dalam klasifikasi benda sehingga minat belajar anak berkurang.

Berdasarkan permasalahan yang dihadapi tersebut, maka peneliti berusaha merancang suatu kegiatan yang menarik dan menyenangkan bagi anak untuk meningkatkan kemampuan kognitif melalui kegiatan klasifikasi benda. Selanjutnya, peneliti bersama guru Kelompok B TK Tunas Mandiri sepakat untuk berkolaborasi dan menjadi mitra dalam kegiatan penelitian ini.

Penelitian yang dilakukan yaitu dua siklus setiap siklus terdiri atas empat rangkaian kegiatan harian. Pada siklus I terdiri atas perencanaan, pelaksanaan, pengamatan, dan refleksi. Hal-hal yang dilakukan dalam tahap ini adalah sebagai berikut: a) membuat skenario 
pembelajaran berupa Rencana Program Pembelajaran Harian (RPPH) untuk siklus I pada pertemuan I, pertemuan II, pertemuan III dan pertemuan IV, yang mengacu pada pembelajaran peningkatan kemampuan kognitif anak melalui kegiatan klasifikasi benda; b) menyiapkan media pembelajaran berupaposter gambar dan kartu gambar buah-buahan yang digunakan untuk kegiatan klasifikasi; c) membuat lembar observasi aktivitas guru dan anak selama proses pembelajaran; dan d) menyediakan alat evaluasi untuk siklus I.

Pelaksanaan tindakan siklus I pertemuan I dilaksanakan pada hari senin, 2 April 2018, dari pukul 7.15-10.30 WITA di kelompok B dengan jumlah sebanyak 16 orang anak didik. Adapun indikator yang akan dicapai oleh anak didik pada pertemuan ini yaitu anak mampu mengklasifikasikan benda berdasarkan warna yang sama.

Telah menjadi kebiasaan setiap pagi melakukan apel pagi di halaman sekolah, guru mengatur anak didik berbaris dengan rapi sesuai dengan kelas masing-masing. Selanjutnya setelah berbaris guru mengarahkan anak untuk masuk ke dalam ruangan tidak lupa pula guru menyuruh anak didik untuk merapikan sepatu di tempat yang telah disediakan. Kemudian anakanak duduk melingkar dengan rapi, setelah itu guru mengucapkan salam kemudian berdoa sebelum belajar dan dilanjutkan dengan membaca surah al-fatiha serta surah-surah pendek dan bernyanyi bersama, kegiatan tersebut dilakukan rutin setiap harinya.

Pada kegiatan inti guru bercerita terlebih dahulu tentang tema yang dibawakan, setelah itu guru menjelaskan maksud dari kegiatan yang akan dilakukan. Guru menggunakan media kartu gambar buah dalam kegiatan klasifikasi berdasarkan warna yang sama. Kemudian meminta anak untuk mengklasifikasikan kartu gambar buah yang sudah disediakan berdasarkan warna merah, tidak merah.

Pada kegiatan akhir dimana guru mempersilahkan dan mengarahkan anak untuk mencuci tangan diluar rungan dan mengambil bekal, kemudian masuk kembali di dalam kelas berdoa sebelum makan setelah selesai berdoa anak makan bersama temannya. Setelah selesai makan anak merapikan tempat makannya dan kembali mencuci tangan dan membaca doa sesudah makan. Setelah itu guru memberikan nasehat-nasehat serta kesimpulan tentang kegiatan yang telah dilakukan, kemudian guru mempersiapkan anak untuk pulang dan guru membimbing anak untuk mengucapkan doa keselamatan dan doa pulang sekolah serta syair pulang sekolah dan di akhiri dengan ucapan salam.

Pelaksanaan tindakan siklus I pertemuan II dilaksanakan pada hari selasa 3 April 2018, dari pukul 7.15-10.30 WITA di kelompok B dengan jumlah anak sebanyak 16 orang. Adapun indikator yang akan dicapai oleh anak didik pada pertemuan ini adalah lanjutan dari indikator sebelumnya, yaitu anak mampu mengklasifikasikan benda berdasarkan bentuk lonjong, tidak lonjong.

Telah menjadi kebiasaan setiap pagi melakukan apel pagi di halaman sekolah, guru mengatur anak didik berbaris dengan rapi sesuai dengan kelas masing-masing. Selanjutnya setelah berbaris guru mengarahkan anak untuk masuk ke dalam ruangan tidak lupa pula guru menyuruh anak didik untuk merapikan sepatu di tempat yang telah disediakan. Kemudian anakanak duduk melingkar dengan rapi, setelah itu guru mengucapkan salam kemudian berdoa sebelum belajar dan dilanjutkan dengan membaca surah al-fatiha serta surah-surah pendek dan bernyanyi bersama, kegiatan tersebut dilakukan rutin setiap harinya.

Pada kegiatan inti terlebih dahulu guru bercerita tentang tema yang akan dibawakan, setelah itu guru menjelaskan maksud dari kegiatan yang akan dilakukan. Guru menggunakan media gambar buah dalam kegiatan mengklasifikasikan gambar buah berdasarkan bentuk yang sama. Kemudian meminta anak untuk mengklasifikasikan gambar buah yang sudah disediakan berdasarkan bentuk lonjong, tidak lonjong.

Pada kegiatan akhir dimana guru mempersilahkan dan mengarahkan anak untuk mencuci tangan diluar rungan dan mengambil bekal, kemudian masuk kembali di dalam kelas berdoa sebelum makan setelah selesai berdoa anak makan bersama temannya. Setelah selesai makan anak merapikan tempat makannya dan kembali mencuci tangan dan membaca doa sesudah makan. Setelah itu guru memberikan nasehat-nasehat serta kesimpulan tentang kegiatan yang telah dilakukan, kemudian guru mempersiapkan anak untuk pulang dan guru membimbing anak untuk mengucapkan doa keselamatan dan doa pulang sekolah serta syair pulang sekolah dan di akhiri dengan ucapan salam.

Pelaksanaan tindakan siklus I pertemuan III dilaksanakan pada hari rabu 4 April 2018, 
dari pukul 7.15-10.30 WITA di kelompok B dengan jumlah anak sebanyak 16 orang. Adapun indikator yang akan dicapai oleh anak didik pada pertemuan ini adalah lanjutan dari indikator sebelumnya, yaitu anak mampu mengklasifikasikan benda berdasarkan ukuran besar, tidak besar.

Telah menjadi kebiasaan setiap pagi melakukan apel pagi di halaman sekolah, guru mengatur anak didik berbaris dengan rapi sesuai dengan kelas masing-masing. Selanjutnya setelah berbaris guru mengarahkan anak untuk masuk ke dalam ruangan tidak lupa pula guru menyuruh anak didik untuk merapikan sepatu di tempat yang telah disediakan. Kemudian anakanak duduk melingkar dengan rapi, setelah itu guru mengucapkan salam kemudian berdoa sebelum belajar dan dilanjutkan dengan membaca surah al-fatiha serta surah-surah pendek dan bernyanyi bersama, kegiatan tersebut dilakukan rutin setiap harinya.

Pada kegiatan inti terlebih dahulu guru bercerita tentang tema yang akan dibawakan, setelah itu guru menjelaskan maksud dari kegiatan yang akan dilakukan. Guru menggunakan media gambar buah dalam kegiatan mengklasifikasikan gambar buah berdasarkan ukuran yang sama. Kemudian meminta anak untuk mengklasifikasikan kartu gambar buah yang sudah disediakan berdasarkan ukuran besar, tidak besar.

Pada kegiatan akhir dimana guru mempersilahkan dan mengarahkan anak untuk mencuci tangan diluar rungan dan mengambil bekal, kemudian masuk kembali di dalam kelas berdoa sebelum makan setelah selesai berdoa anak makan bersama temannya. Setelah selesai makan anak merapikan tempat makannya dan kembali mencuci tangan dan membaca doa sesudah makan. Setelah itu guru memberikan nasehat-nasehat serta kesimpulan tentang kegiatan yang telah dilakukan, kemudian guru mempersiapkan anak untuk pulang dan guru membimbing anak untuk mengucapkan doa keselamatan dan doa pulang sekolah serta syair pulang sekolah dan di akhiri dengan ucapan salam.

Pelaksanaan tindakan siklus I pertemuan IV dilaksanakan pada hari kamis 5 April 2018, dari pukul 7.15-10.30 WITA di kelompok B dengan jumlah anak sebanyak 16 orang. Adapun indikator yang akan dicapai oleh anak didik pada pertemuan ini adalah lanjutan dari indikator sebelumnya, yaitu anak mampu mengklasifikasikan benda berdasarkan cirinya.
Telah menjadi kebiasaan setiap pagi melakukan apel pagi di halaman sekolah, guru mengatur anak didik berbaris dengan rapi sesuai dengan kelas masing-masing. Selanjutnya setelah berbaris guru mengarahkan anak untuk masuk ke dalam ruangan tidak lupa pula guru menyuruh anak didik untuk merapikan sepatu di tempat yang telah disediakan. Kemudian anakanak duduk melingkar dengan rapi, setelah itu guru mengucapkan salam kemudian berdoa sebelum belajar dan dilanjutkan dengan membaca surah al-fatiha serta surah-surah pendek dan bernyanyi bersama, kegiatan tersebut dilakukan rutin setiap harinya.

Pada kegiatan inti terlebih dahulu guru bercerita tentang tema yang akan dibawakan, setelah itu guru menjelaskan maksud dari kegiatan yang akan dilakukan. Guru menggunakan media gambar buah dalam kegiatan mengklasifikasikan gambar buah berdasarkan warna, bentuk, dan ukuran yang sama. Kemudian meminta anak untuk mengklasifikasikan gambar buah yang sudah disediakan berdasarkan cirinya (kasar, tidak kasar).

Pada kegiatan akhir dimana guru mempersilahkan dan mengarahkan anak untuk mencuci tangan diluar rungan dan mengambil bekal, kemudian masuk kembali di dalam kelas berdoa sebelum makan setelah selesai berdoa anak makan bersama temannya. Setelah selesai makan anak merapikan tempat makannya dan kembali mencuci tangan dan membaca doa sesudah makan. Setelah itu guru memberikan nasehat-nasehat serta kesimpulan tentang kegiatan yang telah dilakukan, kemudian guru mempersiapkan anak untuk pulang dan guru membimbing anak untuk mengucapkan doa keselamatan dan doa pulang sekolah serta syair pulang sekolah dan di akhiri dengan ucapan salam.

Selama proses pembelajaran berlangsung, gurusebagai observer mengamati jalannya pembelajaran dengan menggunakn lembar observasi untuk guru dan lembar observasi untuk anak. Kegiatan observasi dilakukan bersamaan dengan pelaksanaan tindakan untuk setiap pertemuan pada siklus I.

Hasil analisis observasi guru sesuai dengan lembar observasi sebanyak 15 aspek yang diamati. Pada siklus I skor yang dicapai oleh guru dari 15 aspek hanya 11 aspek atau sebesar 73,3\% diantaranya: (1) Guru mengucapkan salam sebelum memulai pembelajaran; (2) Guru mengarahkan anak 
untuk berdo'a sebelum belajar; (3) Guru melakukan apersepsi yang berkaitan dengan tema/sub tema; (4) Guru menyiapkan dan perkenalkan media kartu bergambar buahbuahan; (5) Guru menjelaskan kegiatan yang akan dilakukan; (6) Guru meminta anak untuk mengklasifikasikan kartu gambar buah-buahan berdasarkan warna merah, tidak merah; (7) Guru meminta anak untuk mengklasifikasikan kartu gambar buah-buahan berdasarkan bentuk lonjong, tidak lonjong; (8) Guru meminta anak untuk mengklasifikasikan kartu gambar buahbuahan berdasarkan ukuran besar, tidak besar; (9) Guru meminta anak untuk mengklasifikasikan kartu gambar buah-buahan berdasarkan cirinya (kasar, tidak kasar); (10) Guru melakukan tanya jawab mengenai kegiatan yang telah berlangsung dari awal hingga akhir kegiatan; (11) Guru mengarahkan anak untuk bernyanyi serta berdo'a sebelum pulang. Sedangkan yang tidak tercapai sebanyak sebanyak 4 aspek atau sebesar 26,7\% diantaranya : (1) Guru tidak menyampaikan tujuan pembelajaran; (2) Guru tidak meminta anak untuk memperhatikan kegiatan yang akan dilakukan; (3) Guru tidak mengajukan pertanyaan kepada anak dengan tujuan untuk mengetahui sejauh mana pemahaman anak tentang pembelajaran yang telah diberikan; (4) Guru memberikan kesimpulan terhadap kegiatan yang dilakukan. Untuk lebih jelasnya dapat dilihat pada histogram berikut:

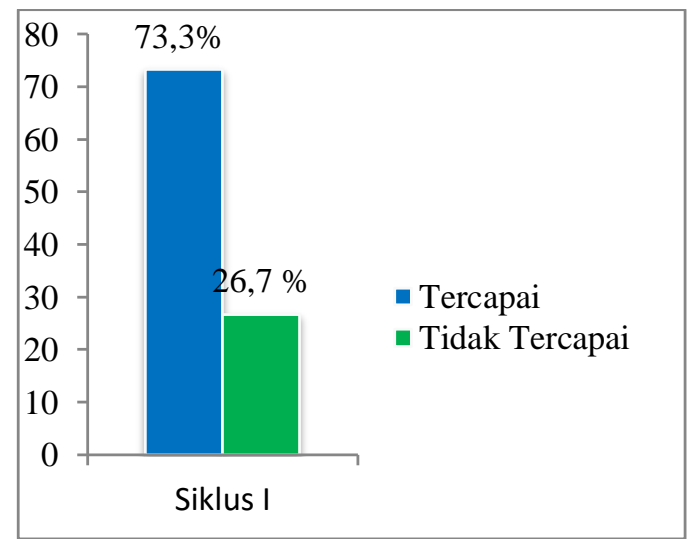

Gambar1.Histogram Hasil Analisis Aktivitas Mengajar Guru Siklus I

Berdasarkan histogram aktivitas mengajar guru bahwa hasil aktivitas mengajar guru pada siklus I selama empat kali pertemuan baru mencapai $73,3 \%$. Sedangkan aktivitas mengajar guru yang belum tercapai yaitu $26,7 \%$ dengan demikian hasil aktivitas mengajar guru pada siklus I belum maksimal sedangkan standar ketercapaian aktivitas mengajar guru yang harus dicapai minimal $85 \%$ sehingga dapat dikatakan berhasil.

Analisis hasil observasi anak sesuai dengan lembar observasi pada siklus I sebanyak 12 aspek yang diamati diharapkan tercapai, namun yang tercapai sebanyak 8 aspek atau sebesar 66,7\% diantaranya: (1) Anak menjawab salam; (2) Anak mengikuti intruksi guru untuk beroda sebelum belajar; (3) Anak memperhatikan guru saat memperkenalkan media pembelajaran; (4) Anak menklasifikasikan kartu gambar buah-buahan berdasarkan warna merah, tidak merah sesuai yang diperintahkan oleh guru; (5) Anak mengklasifikasikan kartu gambar buah-buahan berdasarkan bentuk lonjong, tidak lonjong sesuai yang diperintahkan oleh guru; (6) Anak mengklasifikasikan kartu gambar buah-buahan berdasarkan ukuran besar, tidak besar sesuai apa yang diperintahkan oleh guru; (7) Anak mengklasifikasikan kartu gambar buah-buahan berdasarkan cirinya (kasar, tidak kasar) sesuai apa yang diperintahkan oleh guru; (8) Anak mendengarkan arahan guru untuk bernyanyi serta berdo'a sebelum pulang. Sedangkan yang tidak tercapai sebanyak 4 aspek atau sebesar $33,3 \%$ diantaranya : (1) Anak tidak memperhatikan guru saat penyampaian apersepsi; (2) Anak tidak memperhatikan penjelasan guru tentang kegiatan yang akan dilakukan; (3) Anak tidak melakukan tanya jawab dengan guru mengenai kegiatan yang telah dilakukan dari awal hingga akhir kegiatan; (4) Anak tidak mendengarkan kesimpulan terhadap kegiatan yang dilakukan. Untuk lebih jelasnya dapat dilihat pada histogram berikut:

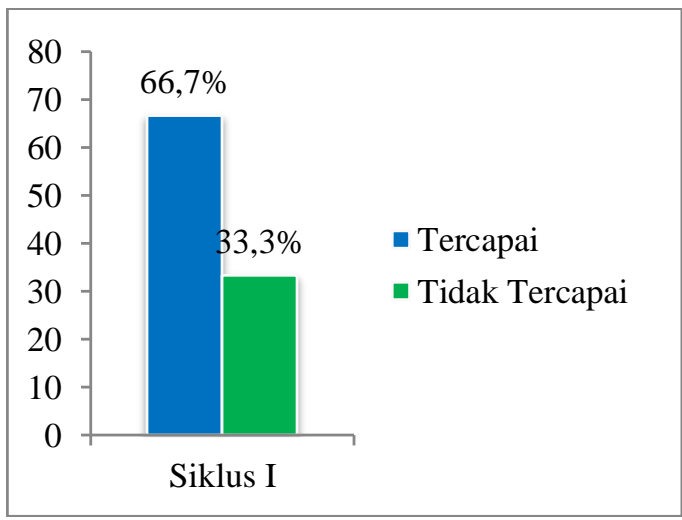

Gambar 2.Histogram Hasil Analisis Aktivitas Belajar Anak Didik Siklus I 
Berdasarkan histogram aktivitas belajar anak bahwa hasil aktivitas belajar anak pada siklus I selama empat kali pertemuan baru mencapai $66,7 \%$. Sedangkan aktivitas belajar anak yang belum tercapai yaitu 33,3\% dengan demikian hasil aktivitas belajar anak pada siklus I belum maksimal sedangkan standar ketercapaian aktivitas belajar anak yang harus dicapai minimal $85 \%$ sehingga dapat dikatakan berhasil.

Tabel 1. Nilai Klasikal pada Siklus I

\begin{tabular}{lcc}
\hline Kategori & Jumlah & Persentase \\
\hline $\begin{array}{l}\text { Banyaknya anak } \\
\text { didik yang } \\
\text { memperoleh nilai }\end{array}$ & 4 & $25 \%$ \\
BSB & & \\
\hline $\begin{array}{l}\text { Banyaknya anak } \\
\text { didik yang } \\
\text { memperoleh nilai }\end{array}$ & 6 & $37,5 \%$ \\
BSH & & \\
\hline $\begin{array}{l}\text { Banyaknya anak } \\
\text { didik yang } \\
\text { memperoleh nilai }\end{array}$ & 4 & $25 \%$ \\
MB & & \\
\hline $\begin{array}{l}\text { Banyaknya anak } \\
\text { didik yang } \\
\text { memperoleh nilai BB }\end{array}$ & 2 & $12,5 \%$ \\
\hline \multicolumn{1}{c}{ Jumlah } & 16 & $100 \%$ \\
\hline
\end{tabular}

Berdasarkan hasil yang diperoleh pada tabel 1 terlihat bahwa secara klasikal kegiatan meningkatkan kemampuan kognitif anak melalui kegiatan klasifikasi benda di Kelompok B TK Tunas Mandiri Kabupaten Bombana pada tahap evaluasi siklus I, rata-rata anak didik memperoleh nilai bintang $(* * *)$ atau Berkembang Sesuai Harapan (BSH) dengan persentase $37,5 \%$ yaitu 6 orang anak didik dari 16 orang anak secara keseluruhan. Nilai bintang (****) atau berkembang Sangat Baik (BSB) dengan persentase $25 \%$ yaitu diperoleh 4 orang anak didik, untuk nilai bintang (**) atau Mulai Berkembang (MB) dengan persentase $25 \%$ yaitu diperoleh 4 orang anak didik, sedangkan untuk nilai bintang (*) atau Belum Berkembang (BB) dengan persentase $12,5 \%$ yaitu diperoleh 1 orang anak didik, maka dapat dikatakan bahwa penelitian tindakan ini belum terselesaikan dan hal ini akan dilanjutkan pada tahapan siklus selanjutnya yaitu siklus II.

Dari hasil yang diperoleh pada tahap kegiatan penelitian tindakan siklus I dan hasil temuan-temuan yang diperoleh, maka peneliti yang bekerjasama dengan guru Kelompok B menilai dan mendiskusikan kelemahan dan kekurangan-kekurangan yang terdapat pada pelaksanaan tindakan siklus I, serta harus segera melaksanakan persiapan dan membuat perencanaan dengan matang, segala yang dilakukan pada tindakan siklus I harus dicermati dan diperbaiki kembali. Setelah mengetahui kekurangan yang terjadi pada siklus I, baik itu yang dilakukan oleh guru maupun anak, maka pada pembelajaran siklus II guru akan mencoba meminimalisir kesalahan-kesalahan yang dilakukan sebelumnya, sehingga hasil belajar dengan menggunakan kegiatan klasifikasi benda sesuai dengan yang diharapkan yaitu mencapai indikator kinerja minimal $85 \%$.

Pelaksanaan tindakan siklus I pertemuan II dilaksanakan pada hari senin, 9 April 2018, dari pukul 7.15-10.30 WITA di kelompok B dengan jumlah sebanyak 16 orang anak didik. Adapun indikator yang akan dicapai oleh anak didik pada pertemuan ini yaitu anak mampu mengklasifikasikan benda berdasarkan warna yang sama.

Telah menjadi kebiasaan setiap pagi melakukan apel pagi di halaman sekolah, guru mengatur anak didik berbaris dengan rapi sesuai dengan kelas masing-masing. Selanjutnya setelah berbaris guru mengarahkan anak untuk masuk ke dalam ruangan tidak lupa pula guru menyuruh anak didik untuk merapikan sepatu di tempat yang telah disediakan. Kemudian anakanak duduk melingkar dengan rapi, setelah itu guru mengucapkan salam kemudian berdoa sebelum belajar dan dilanjutkan dengan membaca surah al-fatiha serta surah-surah pendek dan bernyanyi bersama, kegiatan tersebut dilakukan rutin setiap harinya.

Pada kegiatan inti guru bercerita terlebih dahulu tentang tema yang dibawakan, setelah itu guru menjelaskan maksud dari kegiatan yang akan dilakukan. Guru menggunakan media kartu gambar buah dalam kegiatan klasifikasi berdasarkan warna yang sama. Kemudian meminta anak untuk mengklasifikasikan kartu gambar buah yang sudah disediakan berdasarkan warna merah, tidak merah.

Pada kegiatan akhir dimana guru mempersilahkan dan mengarahkan anak untuk mencuci tangan diluar rungan dan mengambil bekal, kemudian masuk kembali di dalam kelas berdoa sebelum makan setelah selesai berdoa anak makan bersama temannya. Setelah selesai makan anak merapikan tempat makannya dan kembali mencuci tangan dan membaca doa 
sesudah makan. Setelah itu guru memberikan nasehat-nasehat serta kesimpulan tentang kegiatan yang telah dilakukan, kemudian guru mempersiapkan anak untuk pulang dan guru membimbing anak untuk mengucapkan doa keselamatan dan doa pulang sekolah serta syair pulang sekolah dan di akhiri dengan ucapan salam.

Pelaksanaan tindakan siklus II pertemuan II dilaksanakan pada hari selasa 10 April 2018, dari pukul 7.15-10.30 WITA di kelompok B dengan jumlah anak sebanyak 16 orang. Adapun indikator yang akan dicapai oleh anak didik pada pertemuan ini adalah lanjutan dari indikator sebelumnya, yaitu anak mampu mengklasifikasikan benda berdasarkan bentuk yang sama.

Telah menjadi kebiasaan setiap pagi melakukan apel pagi di halaman sekolah, guru mengatur anak didik berbaris dengan rapi sesuai dengan kelas masing-masing. Selanjutnya setelah berbaris guru mengarahkan anak untuk masuk ke dalam ruangan tidak lupa pula guru menyuruh anak didik untuk merapikan sepatu di tempat yang telah disediakan. Kemudian anakanak duduk melingkar dengan rapi, setelah itu guru mengucapkan salam kemudian berdoa sebelum belajar dan dilanjutkan dengan membaca surah al-fatiha serta surah-surah pendek dan bernyanyi bersama, kegiatan tersebut dilakukan rutin setiap harinya.

Pada kegiatan inti terlebih dahulu guru bercerita tentang tema yang akan dibawakan, setelah itu guru menjelaskan maksud dari kegiatan yang akan dilakukan. Guru menggunakan media gambar buah dalam kegiatan mengklasifikasikan gambar buah berdasarkan bentuk yang sama. Kemudian meminta anak untuk mengklasifikasikan gambar buah yang sudah disediakan berdasarkan bentuk lonjong, tidak lonjong.

Pada kegiatan akhir dimana guru mempersilahkan dan mengarahkan anak untuk mencuci tangan diluar rungan dan mengambil bekal, kemudian masuk kembali di dalam kelas berdoa sebelum makan setelah selesai berdoa anak makan bersama temannya. Setelah selesai makan anak merapikan tempat makannya dan kembali mencuci tangan dan membaca doa sesudah makan. Setelah itu guru memberikan nasehat-nasehat serta kesimpulan tentang kegiatan yang telah dilakukan, kemudian guru mempersiapkan anak untuk pulang dan guru membimbing anak untuk mengucapkan doa keselamatan dan doa pulang sekolah serta syair pulang sekolah dan di akhiri dengan ucapan salam.

Pelaksanaan tindakan siklus II pertemuan III dilaksanakan pada hari rabu 11 April 2018, dari pukul 7.15-10.30 WITA di kelompok B dengan jumlah anak sebanyak 16 orang. Adapun indikator yang akan dicapai oleh anak didik pada pertemuan ini adalah lanjutan dari indikator sebelumnya, yaitu anak mampu mengklasifikasikan benda berdasarkan ukuran yang sama.

Telah menjadi kebiasaan setiap pagi melakukan apel pagi di halaman sekolah, guru mengatur anak didik berbaris dengan rapi sesuai dengan kelas masing-masing. Selanjutnya setelah berbaris guru mengarahkan anak untuk masuk ke dalam ruangan tidak lupa pula guru menyuruh anak didik untuk merapikan sepatu di tempat yang telah disediakan. Kemudian anakanak duduk melingkar dengan rapi, setelah itu guru mengucapkan salam kemudian berdoa sebelum belajar dan dilanjutkan dengan membaca surah al-fatiha serta surah-surah pendek dan bernyanyi bersama, kegiatan tersebut dilakukan rutin setiap harinya.

Pada kegiatan inti terlebih dahulu guru bercerita tentang tema yang akan dibawakan, setelah itu guru menjelaskan maksud dari kegiatan yang akan dilakukan. Guru menggunakan media gambar buah dalam kegiatan mengklasifikasikan gambar buah berdasarkan ukuran yang sama. Kemudian meminta anak untuk mengklasifikasikan kartu gambar buah yang sudah disediakan berdasarkan ukuran besar, tidak besar.

Pada kegiatan akhir dimana guru mempersilahkan dan mengarahkan anak untuk mencuci tangan diluar rungan dan mengambil bekal, kemudian masuk kembali di dalam kelas berdoa sebelum makan setelah selesai berdoa anak makan bersama temannya. Setelah selesai makan anak merapikan tempat makannya dan kembali mencuci tangan dan membaca doa sesudah makan. Setelah itu guru memberikan nasehat-nasehat serta kesimpulan tentang kegiatan yang telah dilakukan, kemudian guru mempersiapkan anak untuk pulang dan guru membimbing anak untuk mengucapkan doa keselamatan dan doa pulang sekolah serta syair pulang sekolah dan di akhiri dengan ucapan salam.

Pelaksanaan tindakan siklus II pertemuan IV dilaksanakan pada hari kamis 12 April 2018, dari pukul 7.15-10.30 WITA di kelompok B dengan jumlah anak sebanyak 16 orang. Adapun 
indikator yang akan dicapai oleh anak didik pada pertemuan ini adalah lanjutan dari indikator sebelumnya, yaitu anak mampu mengklasifikasikan benda berdasarkan cirinya (kasar, tidak kasar).

Telah menjadi kebiasaan setiap pagi melakukan apel pagi di halaman sekolah, guru mengatur anak didik berbaris dengan rapi sesuai dengan kelas masing-masing. Selanjutnya setelah berbaris guru mengarahkan anak untuk masuk ke dalam ruangan tidak lupa pula guru menyuruh anak didik untuk merapikan sepatu di tempat yang telah disediakan. Kemudian anakanak duduk melingkar dengan rapi, setelah itu guru mengucapkan salam kemudian berdoa sebelum belajar dan dilanjutkan dengan membaca surah al-fatiha serta surah-surah pendek dan bernyanyi bersama, kegiatan tersebut dilakukan rutin setiap harinya.

Pada kegiatan inti terlebih dahulu guru bercerita tentang tema yang akan dibawakan, setelah itu guru menjelaskan maksud dari kegiatan yang akan dilakukan. Guru menggunakan media gambar buah dalam kegiatan mengklasifikasikan gambar buah berdasarkan warna, bentuk, dan ukuran yang sama. Kemudian meminta anak untuk mengklasifikasikan gambar buah yang sudah disediakan berdasarkan cirinya (kasar, tidak kasar).

Pada kegiatan akhir dimana guru mempersilahkan dan mengarahkan anak untuk mencuci tangan diluar rungan dan mengambil bekal, kemudian masuk kembali di dalam kelas berdoa sebelum makan setelah selesai berdoa anak makan bersama temannya. Setelah selesai makan anak merapikan tempat makannya dan kembali mencuci tangan dan membaca doa sesudah makan. Setelah itu guru memberikan nasehat-nasehat serta kesimpulan tentang kegiatan yang telah dilakukan, kemudian guru mempersiapkan anak untuk pulang dan guru membimbing anak untuk mengucapkan doa keselamatan dan doa pulang sekolah serta syair pulang sekolah dan di akhiri dengan ucapan salam.

Selama proses pembelajaran berlangsung, guru sebagai observer mengamati jalannya pembelajaran dengan menggunakn lembar observasi untuk guru dan lembar observasi untuk anak. Kegiatan observasi dilakukan bersamaan dengan pelaksanaan tindakan untuk setiap pertemuan pada siklus II.

Hasil analisis observasi guru sesuai dengan lembar observasi sebanyak 15 aspek yang diamati. Pada siklus II skor yang dicapai oleh guru dari 15 aspek hanya 14 aspek atau sebesar 93,3\% diantaranya: (1) Guru mengucapkan salam sebelum memulai pembelajaran; (2) Guru megarahkan anak untuk berdo'a sebelum belajar; (3) Guru menyampaikan tujuan pembelajaran; (4) Guru melakukan apersepsi yang berkaitan dengan tema/sub tema; (5) Guru menyiapkan dan perkenalkan media kartu bergambar buahbuahan; (6) Guru menjelaskan kegiatan yang akan dilakukan; (7) Guru meminta anak untuk memperhatikan kegiatan yang akan dilakukan; (8) Guru mengajukan pertanyaan kepada anak dengan tujuan untuk mengetahui sejauh mana pemahaman anak tentang pembelajaran yang telah diberikan; (9) Guru meminta anak untuk mengklasifikasikan kartu gambar buah-buahan berdasarkan warna merah, tidak merah; (10) Guru meminta anak untuk mengklasifikasikan kartu gambar buah-buahan berdasarkan bentuk lonjong, tidak lonjong; (11) Guru meminta anak untuk mengklasifikasikan kartu gambar buahbuahan berdasarkan ukuran besar, tidak besar; (12) Guru meminta anak untuk mengklasifikasikan kartu gambar buah-buahan berdasarkan cirinya (kasar, tidak kasar); (13) Guru melakukan tanya jawab mengenai kegiatan yang telah berlangsung dari awal hingga akhir kegiatan; (14) Guru mengarahkan anak untuk bernyanyi serta berdo'a sebelum pulang. sedangkan yang tidak tercapai sebanyak 1 aspek atau sebesar 6,7\% diantaranya: (1) Guru tidak memberikan kesimpulan terhadap kegiatan yang dilakukan. Untuk lebih jelasnya dapat dilihat pada histogram berikut:

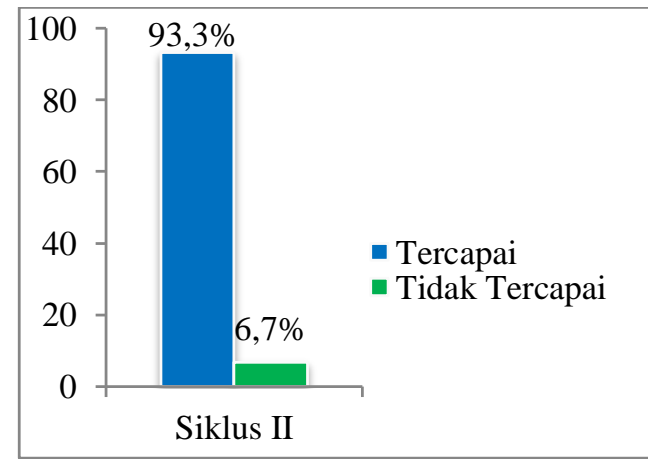

Gambar 3. Histogram Hasil Analisis Aktivitas Mengajar Guru Siklus II

Berdasarkan histogram aktivitas mengajar guru bahwa hasil aktivitas mengajar guru pada siklus II selama empat kali pertemuan baru mencapai 9,33\%. Sedangkan aktivitas mengajar 
guru yang belum tercapai yaitu $6,7 \%$ dengan demikian hasil aktivitas mengajar guru pada siklus II dikatakan sudah maksimal dengan standar ketercapaian aktivitas mengajar guru yang harus dicapai minimal $85 \%$.

Analisis hasil observasi anak sesuai dengan lembar observasi pada siklus II sebanyak 12 aspek yang diamati diharapkan tercapai, namun yang tercapai sebanyak 11 aspek atau sebesar 91,7\%, diantaranya: (1) Anak menjawab salam; (2) Anak mengikuti intruksi guru untuk beroda sebelum belajar; (3) Anak memperhatikan guru saat penyampaian apersepsi; (4) Anak memperhatikan guru saat memperkenalkan media pembelajaran; (5) Anak memperhatikan penjelasan guru tentang kegiatan yang akan dilakukan; (6) Anak men klasifikasikan kartu gambar buah-buahan berdasarkan warna merah, tidak merah sesuai yang diperintahkan oleh guru; (7) Anak mengklasifikasikan kartu gambar buah-buahan berdasarkan bentuk lonjong, tidak lonjong sesuai yang diperintahkan oleh guru; (8) Anak mengklasifikasikan kartu gambar buah-buahan berdasarkan ukuran besar, tidak besar sesuai apa yang diperintahkan oleh guru; (9) Anak mengklasifikasikan kartu gambar buah-buahan berdasarkan cirinya (kasar, tidak kasar) sesuai apa yang diperintahkan oleh guru; (10) Anak melakukan tanya jawab dengan guru mengenai kegiatan yang telah dilakukan dari awal hingga akhir kegiatan; (11) Anak mendengarkan arahan guru untuk bernyanyi serta berdo'a sebelum pulang. sedangkan yang tidak tercapai sebanyak 1 aspek atau sebesar 8,3\% diantaranya: (1) Anak tidak mendengarkan kesimpulan terhadap kegiatan yang dilakukan Untuk lebih jelasnya dapat dilihat pada histogram berikut:

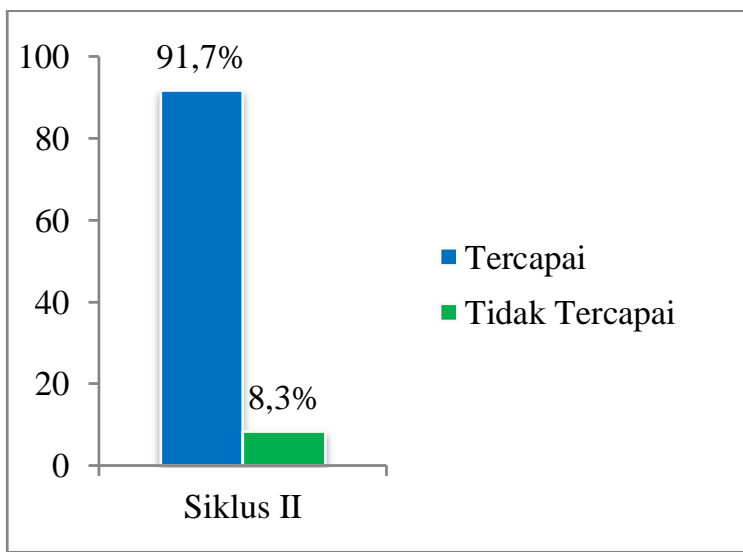

Gambar 4. Histogram Hasil Analisis Aktivitas Belajar Anak Didik Siklus II
Berdasarkan histogram aktivitas belajar anak bahwa hasil aktivitas belajar anak pada siklus II selama empat kali pertemuan baru mencapai 91,7\%. Sedangkan aktivitas mengajar guru yang belum tercapai yaitu 8,3\% dengan demikian hasil aktivitas belajar anak pada siklus II dikatakan sudah maksimal sesuai standar ketercapaian aktivitas belajar anak yang harus dicapai minimal $85 \%$.

Tabel 2. Nilai Klasikal pada Siklus II

\begin{tabular}{lcc}
\hline Kategori & Jumlah & Persentase \\
\hline $\begin{array}{l}\text { Banyaknya anak } \\
\text { didik yang } \\
\text { memperoleh nilai }\end{array}$ & 6 & $37,5 \%$ \\
\begin{tabular}{l} 
BSB \\
\hline $\begin{array}{l}\text { Banyaknya anak } \\
\text { didik yang } \\
\text { memperoleh nilai }\end{array}$
\end{tabular} & 8 & $50 \%$ \\
\begin{tabular}{l} 
BSH \\
\hline $\begin{array}{l}\text { Banyaknya anak } \\
\text { didik yang } \\
\text { memperoleh nilai }\end{array}$
\end{tabular} & 2 & $12,5 \%$ \\
MB & & \\
\hline $\begin{array}{l}\text { Banyaknya anak } \\
\text { didik yang } \\
\text { memperoleh nilai }\end{array}$ & 0 & $0 \%$ \\
BB & & $100 \%$ \\
\hline \multicolumn{1}{c}{ Jumlah } & 16 & \\
\hline
\end{tabular}

Berdasarkan data hasil perolehan nilai anak didik yang ditampilkan pada Tabel 2 di atas, maka dapat disimpulkan program kegiatan meningkat. Walaupun masih terdapat anak didik yang memperoleh nilai bintang $(* *)$ atau Mulai Berkembang (MB) tetapi dapat dikatakan bahwa sebagian anak didik dipandang telah mampu menyelesaikan tugas-tugas yang telah ditetapkan sesuai dengan indikator penilaian dalam penelitian ini khususnya dalam pelaksanaan tindakan siklus II.

Selain itu, dengan perolehan nilai sebesar $87,5 \%$ tersebut telah dicapai oleh 14 orang anak didik, sehingga secara umum dapat dikatakan bahwa program kegiatan atau rangkaian pelaksanaan pembelajaran dalam meningkatkan kemampuan kognitif anak di kelompok B TK Tunas Mandiri Kabupaten Bombana telah terselesaikan dan mencapai target peneliti yaitu indikator keberhasilan minimal $85 \%$.

Jika dilihat dari hasil perhitungan nilai secara klasikal pada siklus II yaitu 87,5\% anak telah mencapai indikator kinerja yaitu minimal $85 \%$ anak memperoleh nilai Berkembang 
Sangan Baik (BSB) dan Berkembang Sesuai Harapan (BSH). Dengan demikian penelitian ini telah berhasil dilaksanakan, maka peneliti dan guru kelompok sepakat untuk tidak melanjutkan pada tahap siklus selanjutnya, dengan kata lain tindakan penelitian ini dihentikan.

\section{KESIMPULAN DAN SARAN}

\section{Kesimpulan}

Berdasarkan analisis data hasil observasi aktivitas mengajar guru pada siklus I diperoleh persentase ketercapaian sebesar 73,3\%. Sedangkan aktivitas belajar anak didik pada siklus I diperoleh persentase ketercapaian sebesar 66,7\%. Pada siklus II, persentase ketercapaian aktivitas mengajar guru mengalami peningkatan sebesar 93,3\%, sedangkan persentase belajar anak pada siklus II mengalami peningkatan sebesar 91,3\%.

Berdasarkan hasil observasi yang telah dilakukan peneliti pada anak didik pada observasi siklus I mencapai persentase sebesar 62,5\% dimana dari 16 anak didik sekitar 10 anak didik yang Berkembang Sangat Baik (BSB) dan Berkembang Sesuai Harapan (BSH). Pada siklus II mengalami peningkatan sebanyak 14 anak didik dengan persentase $87,5 \%$ ketuntasan sesara klasikal yaitu 6 anak didik yang Berkembang Sangat Baik (BSB) dan 8 anak didik yang Berkembang Sesuai Harapan (BSH), dengan selisih peningkatan sebesar $25 \%$ yang diperoleh dari 4 anak didik.

\section{Saran}

Berdasarkan kesimpulan tersebut, maka peneliti menyarankan hal-hal sebagai berikut : 1) Bagi guru, sebaiknya dalam pelaksanaan proses pembelajaran menerapkan hendaknya mempertimbangkan media, metode, materi dan strategi yang tepat untuk anak didik dan guru dituntut untuk selalu kreatif dalam melaksanakan kegiatan-kegiatan untuk meningkatkan minat dan potensi anak didik; 2) Bagi sekolah, diharapkan dapat memberikan dan menyediakan fasilitas yang mendukung kegiatan pembelajaran dalam menerapkan kegiatan klasifikasi benda, mendukung upaya guru dalam menggunakan kegiatan klasifikasi benda untuk meningkatkan kemampuan kognitif anak; 3) Bagi peneliti selanjutnya, diharapkan dapat mengangkat kembali permasalahan yang sama tetapi dengan metode dan strategi yang lain serta tindakan yang berbeda agar dapat memberikan masukan dan temuan-temuan baru dalam mengembangkan kemampuan anak khususnya di taman kanak-kanak secara optimal.

\section{DAFTAR PUSTAKA}

Ali Nugraha, dkk. 2005. Kurikulum dan Bahan Belajar TK. Jakarta: Universitas. Terbuka.

Arikunto, Suharsimi, dkk. 2014. Penelitian Tindakan Kelas. Jakarta: PT. Bumi Aksara.

Depdiknas. 2003. Undang-undang Nomor 20 Tahun 2003 tentang Sistem Pendidikan Nasional Pasal 1 ayat 14 tentang Sistem Pendidikan Nasional. Jakarta: Depdiknas.

Hildayani, Rini. 2005. Psikologi Perkembangan Anak. Jakarta: Universitas. Terbuka.

KBBI (Kamus Besar Bahasa Indonesia). 2005. Jakarta: PT (Persero) penerbitan dan percetakan. Anjani.

Monks, F.J., Knoers, A.M. P. \& Haditono, S.R. 2006. Psikologi Perkembangan Pengantar dalam Berbagai Bagiannya. Yogyakarta: Gadjah Mada University Press.

Sefeldt, Carol \& Barbara A. Wasik. 2008. Pendidikan Anak Usia Dini (menyiapkan Anak Usia Tiga, Empat dan Lima Tahun Masuk Sekolah). Jakarta: PT Indeks.

Siti, Partini Suardiman. 2003. Metode Pengembangan Daya Pikir dan Daya Cipta untuk Anak Usia Dini. Yogyakarta: FIP UNY.

Soemiarti Patmonodewo. 2003. Pendidikan Anak Pra Sekolah. Jakarta:Rineka. Cipta.

Susanto, Ahmad, 2011. Perkembangan Anak Usia Dini. Jakarta: Kencana.

Suyanto, Slamet. 2005. Dasar-Dasar Pendidikan Anak Usia Dini. Yogyakarta: Hikayat.

Suyadi. 2010. Psikologi Belajar Anak Usia Dini. Yogyakarta : Pedagogia.

Wardani Igak \& Wihardi Kuswaya. 2010. Penelitian Tindakan Kelas. Jakarta: Universitas Terbuka.

Witherington,H.C. 2011. Psikologi Pendidikan. Jakarta:Aksara Baru,1999 